Sanja Jukić

sjukic@ffos.hr

\title{
Stripovni stil pjesničkoga subjekta u suvremenom hrvatskome pjesništvu iskustva intermedijalnosti i postintermedijalnosti
}

\begin{abstract}
Jukić Sanja, Stripovni stil pjesničkoga subjekta $u$ suvremenom hrvatskome pjesništvu iskustva intermedijalnosti i postintermedijalnosti (The comic book style of the poetical subject in the contemporary Croatian poetry of intermedial and postintermedial experience). „Poznańskie Studia Slawistyczne” 2. Poznań 2012. Adam Mickiewicz University Press, pp. 169-188. ISBN 978-83-232-2409-9. ISSN 2084-3011.

This paper deals with poetic subjects in the comic book format as presented in the media. The subject of media entity dominates the corpus of texts in intermedial and postintermedial poetry experience. These aspects of Croatian poetry from 1968 up to the present day, whose structures are primarily determined by contacts with different media culture texts, are defined by Goran Rem. This paper explores the ways in which the media intermediates comic book semiotics into the poetic code of that particular part of contemporary Croatian poetry and thus determines the paradigmatic forms of the subject of media/comic book.
\end{abstract}

Keywords: poetic subject, media subject, comic book style, comic book subject, intermedial and postintermedial poetry

Pjesnički subjekt intermedijske, odnosno drugomedijske konstitutivnosti - medijski subjekt, dominantna je instanca ,pjesništva iskustva intermedijalnosti” i ,postintermedijalnosti”, kako smjerove hrvatskoga pjesništva od 1968. do danas, a koji su primarno strukturno determinirani kontaktima s različitim tekstovima medijske kulture, imenuje Goran Rem¹.

${ }^{1}$ „Od 1968. kreće uspostavljanje punoga kontinuiteta osjetljivosti za jezike drugih umjetnosti, massmedija i kulture". G. Rem, Koreografija teksta 1, Zagreb 2003, str. 25. Svojevrsna dopuna i nastavak te studije je knjiga G. Rem, Pogo i tekst, Zagreb 2011. 
Ovaj rad bavi se paradigmatskim oblicima stripovnoga lika medijskog subjekta u tom dijelu korpusa suvremenog hrvatskoga pjesništva.

\section{Medijski subjekt pjesništva iskustva intermedijalnosti i postintermedijalnosti}

Medijski se subjekt, kao strategijski i pozicijski nova instanca u suvremenome hrvatskom pjesništvu, odmiče od prethodne mu tekstualne strukture subjekta utemeljene na eksplicitnom (auto)tematiziranju egzistencijalne problematike. I medijski subjekt, doduše, posreduje informaciju o stanju humanitetne egzistencije u kontekstu medijske kulture drugoga dijela 20. i početka 21. stoljeća, ali to je asocirana (,kolateralna”) informacija, koja je zapravo nusproizvod primarne subjektove strategije osvješćivanja uronjenosti poetskoga koda u polimedijski kulturalni kontekst. Medijski se subjekt, dakle, odriče bilo kakvoga emocionalnog ili eksplicitno filozofijskog angažmana spram sadržaja što ga čini, uvjetno rečeno, kakva lirska radnja. On je, funkcijski, projekcijska instanca kroz čiji se glas uvode drugomedijski govori, što ga čini kodno elastičnom, ali i implicitno ili eksplicitno metatekstnom, odnosno metamedijskom strukturom. Medijski subjekt je subjekt koji je proizvodnjom djelatno zaokupljen, bilo da je riječ o prvoosobnoj instanci, bilo da je riječ (što je češće u djelomice ili potpuno vizualno strukturiranim tekstovima) o subjektu teksta kojega tekstualna dislociranost jača kao takvu metakodnu instancu.

Medijski subjekt u međumedijskim kontaktima koristi konvencionalni semiotički materijal neknjiževnih medija, znakove stilske heterogenosti unutar estetskih geneza tih drugih medija, ali najčešće stilske odmake i eksperimente.

Medijskom subjektu nije bitno prenijeti sadržaj, već upotrijebiti semiotičku strukturu neknjiževnog medija (umjetničkog ili neumjetničkog) kao sredstvo preoznačavanja svoje matične poetske strukture, ali i, povratno, kao informaciju o strukturi medija koja je upotrijebljena kao instrument metajezičnih intervencija.

Drugim riječima, medijski subjekt pjesničkoga teksta uvijek je djelatno barem dvosmjerni metasubjekt te tranzitna instanca kroz koju protječu 
različiti medijski imputi što ih ona svojim varijabilnim identitetom transponira u strukture poetskoga teksta s ciljem implicitnog ili eksplicitnog artikuliranja komentara spram svih kodova čije signale emitira.

\section{Stripovni stil pjesničkog subjekta}

S obzirom da hrvatska poezija od sredine 20. stoljeća, u skladu s kulturom u kojoj dominiraju vizualni mediji, i sama preispituje svoje strukturne mogućnosti okretanjem drugim semiotičkim sustavima, i to najčešće vizualnima, strip se pokazao odgovarajućim prototekstom jer je, kao i poezija, prostorna umjetnost ${ }^{2}$ te je imanentno semiotički hibridan - što poezija želi biti kako bi provjerila/ekstenzivirala svoje iskazne pa onda i semantičke mogućnosti ${ }^{3}$.

Kako je u intermedijalnoj poeziji medijski subjekt primarna struktura realizacije intermedijskoga kontakta, tako će i u interakciji pjesničkoga teksta i stripovnoga koda lirski subjekt biti posredovatelj i/ili nositelj semantički najvažnijih semiotičkih elemenata stripa.

Te će elemente posredovati parcijalno ili u cijelosti. Kada je riječ o segmentnim preuzimanjima (primjerice, samo citatne aluzije na strip verbalnim znakovima koji oponašaju stripovsko kaligramsko reprezentiranje psihoemocionalnih stanja, kombiniranjem slike i teksta i sl.), nije presudan status referentnoga stripa u kontekstu stripovne poetike jer su

${ }^{2}$ P. Pavličić, Intertekstualnost i intermedijalnost. Tipološki ogled, u: Intertekstualnost \& intermedijalnost, ur. Z. Maković, M. Medarić, D. Oraić, P. Pavličić, Zagreb 1988, str. 157-195.

${ }^{3} \mathrm{Na}$ strip se, kao dio takvoga konteksta sve utjecajnije vizualne kulture, kao strategijski osmišljen prototekst hrvatske intermedijalne poezije, nailazi od kraja 70-ih godina 20 stoljeća (Ljubomir Stefanović) te kasnije u 80-ima (Goran Rem), 90-ima (Tomica Bajsić) i 2000-ima (Alen Galović), dakle kroz sva desetljeća od sredine prošloga stoljeća do danas. Ono što je zajedničko pristupu tih autora stripu jest i svojevrsna reakcija na hrvatski kulturalni kontekst u kojemu se upravo od sredine 70-ih pojavljivanjem časopisa Polet revitalizirala i hrvatska strip-scena (iako se autori koji intermedijaliziraju sa stripom ne referiraju nužno na hrvatske stripove), strip se općenito uzdignuo kao relevantan i te kako prisutan oblik medijske kulture. O povijesti stripa i stripovnim žanrovima pišu Sanjin Dragojević i Hrvoje Frančeski u: S. Dragojević, H. Frančeski, Povijest stripa, u: Uvod u medije (zbornik), ur. Z. Peruško, Zagreb 2011, str. 173-201. 
citatni fragmenti prije svega usmjereni poetološkome restrukturiranju pjesničkoga teksta postupcima drugoga medija. Kod cijelosnih ili barem kompleksnijih strukturnih korelacija pjesme i stripa, intersemiotičnošću se oblikuje i složenija interakcija poetskoga i stripovnoga medija koja uključuje ne samo metajezične, već i metamedijske postupke, što znači da se uspostavlja odnos na razini poetičkih matrica jednoga i drugoga medija pa je prototekst $u$ onim stripovnim vrstama koje narušavaju konvencionalne strukturne postupke stripa pošto je on tradicionalno utemeljen na fabulativnom odnosu spram teme i egzistencijalističkom odnosu spram likova. Dakako, samo motivski intermedijalizmi ne vode računa o strukturnim ograničenjima.

Drugim riječima, kada su posrijedi veći zahvati u stripovni kôd, intermedijalnoj će poeziji biti strukturno najbliži disimilacijski stripovi ${ }^{4}$, i to samo načelno, na razini otpora spram strukturnih konvencija i spram uobičajene semantike motivske građe, dok će struktura subjekta zapravo biti temeljni prostor i generator realizacije svih vrsta kontakata sa stripom i sredstvo razlikovanja semantičkih konotacija u kontaktima s tehnološkim, asimilacijskim $^{5}$ pa i disimilacijskim stripom. O kojemu se god tipu međumedijskoga kontakta radilo, u kontekstu pjesničkoga teksta on uvijek funkcionira dekonstrukcijski u odnosu na rodne značajke pjesme.

Lirski subjekt preuzima identitet i karakterizaciju stripovnoga kao komentar svoje vlastite pozicije i funkcije (primjerice, Alan Ford u poeziji Ljubomira Stefanovića, Lucky Luke u poeziji Gorana Rema, Corto Maltese u poeziji Tomice Bajsića, Srebrni Letač u poeziji Alena Galovića i sl.), a svoje djelovanje proširuje i na ostale strukture pjesničkoga teksta - formu i temu.

${ }^{4}$ Tematsko-motivska i strukturna tipologija stripa razlikuje bajkoliki, tehnološki, asimilacijski i disimilacijski strip. Bajkoliki strip preuzima motive i strukturu bajki, tehnološki je utemeljen na akciji i nasilju kao motivskim konstantama, futuristički je, ali samo iz perspektive čitatelja, dok je iz perspektive strip-junaka budućnost uobičajena svakodnevica u kojoj tehnološka čuda imaju racionalni temelj, asimilacijski je integrativno postavljen spram kulture, umjetnosti, povijesti i društva općenito te ima tendenciju ujednačavanja, dovršavanja, idealiziranja, dok je disimilacijski strip onaj koji također koristi kulturalnu, društveno-povijesnu i umjetničku zbilju, no s tendencijom uspostavljanja opreka, dvosmislenosti, disimilacijskih rezova često humorne prirode i oslobađanja od uobičajenih strukturnih i semantičkih rješenja. Prema: S. Ignjatović, Poetizam stripa, Osijek 1979, str. 59-61.

${ }^{5}$ Ibidem. 
Tako je medijski-stripovni subjekt u tekstu ili subjekt teksta prepoznatljivi citat stripovnog junaka koji svojim djelovanjem oblikuje grafiku teksta ili crtežnim intervencijama oponaša oblik stripovskih kadrova, pri čemu se tematska razina mora uspostaviti kao naracijsko-deskripcijska potpora grafici kako bi se ona identificirala kao stripovna jer strofična pjesma sama po sebi formalno je usporediva sa stripom, osim što odudara vertikalnim smjerom razvijanja radnje (što i ne mora biti razlikovno mjesto ako se uzme u obzir fleksibilnost organizacije slijeda kadrova u stripu). Tematsko-motivska struktura koja se prepoznaje kao stripovna, preslika je ili parafraza stripovne priče koju djelovanje subjekta identificira na jedan od ranije spomenutih načina - kao bajkoliku, tehnološku, asimilacijsku ili disimilacijsku. Dakle, subjekt je taj čije djelovanje određuje kakav će tip prijenosa stripovne stilistike, odnosno njezine resemantizacije u svrhu dekonstrukcije pjesničkoga koda, biti proveden - onaj koji preuzima strukturu i motiviku bajke, onaj koji tehnologijskom futurizmu oduzima dimenziju fantastičnog (u poeziji Alena Galovića), onaj koji pomiruje kulturnocivilizacijske manifestacije u idealiziranim likovima i njihovim pothvatima (u poeziji Tomice Bajsića) ili onaj koji verbalnom znakovnošću palimpsestira stripovnu gradeći metametarazinu semantičkih konotacija - i u odnosu na pjesnički tekst/kôd, i u odnosu na strip (u poeziji Gorana Rema).

Subjekt koji je središnji medij transponiranja stripovne semiotike u kôd pjesničkoga teksta (kao On, Ti ili objektivirano Ja), pokazatelj je dominantne stilske tehnike toga prebacivanja, koja je inače imanentna i stripovnome i poetskome kodu te, stoga, mjesto koje dokazuje potencijal međumedijskoga kontakta ove dvije vrste umjetnosti. Riječ je o sinegdohalnosti.

Sinegdohalnost je u stripu terminološki označena kao zatvorenost, pojava koja prvenstveno upućuje na „mentalni proces zamjećivanja dijelova, ali percipiranja cjeline", , i Scott McCloud određuje ju ,gramatikom stripa" toga postupka, sinegdohalnost, odnosno ,zatvorenost elektroničkih medija

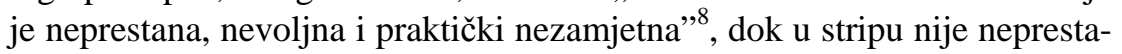
na, a i te kako je voljna i planirana. McCloud u sučeljavanju različitih me-

\footnotetext{
${ }^{6}$ S. McCloud, Kako čitati strip - nevidljivu umjetnost, Zagreb 2005, str. 63.

${ }^{7}$ Ibidem, str. 67.

${ }^{8}$ Ibidem, str. 68 .
} 
dijskih struktura generalizira svoj zaključak i izostavlja uzeti u obzir različitu nakanu različitih elektroničkih medija, odnosno činjenicu kako oni kojima je cilj proizvesti određeni umjetnički efekt zasigurno na isti način kao i strip koriste postupak zatvorenosti, odnosno sinegdohalnosti (primjerice, film). Razlika je u tome što je strip prostorni medij i što je montaža kojom se ostvaruje sinegdohalnost kao stilski obilježena informacija vidljiva, te ce to u primjeni na poetsku strukturu biti eksplicitni signal djelovanja instance medijskoga subjekta teksta.

Dakle, kako su i strip i pjesnički tekst prostorne umjetnosti, obje na isti ili vrlo sličan način provode montažu i sinegdohalnost kao temeljne postupke konstrukcije tekstualnih, odnosno strip-struktura. U obje je, zbog pokretne zamrznutosti njihovih medija, montiranje vidljivi postupak, postupak koji, osim što upućuje na semantičke veze među elementima u nizu, i sam postaje tema s određenom semantičkom vrijednošću. Kako bi se uopće uspostavila nekakva slikovna ili slikovno-verbalna naracija, potrebno je slikovne kadrove povezati, dakle montirati u određeni niz. Kombiniranje sinegdohalnosti iskaza (često realizirano elipsom) i jarka ${ }^{9}$, signal je montaže kao konstrukcijskoga postupka koji stvara određeni uzorak utemeljen na kauzalnoj vezi među slikovnim sastavnicama. Postojanje nekakvog informacijskoga niza koji je montiran s određenom umjetničkom nakanom, preduvjet je za nastanak stilistične situacije, kako ju je postavio Michael Riffaterre, a u kojoj će određeni informacijski kontinuitet prekinuti njemu kontrastni element. Kako je stilska vrijednost, prema Riffaterreu, u kontrastu nekog neprekinutog uzorka i nepredvidivog elementa, ${ }^{10}$ pretpostaviti je kako se polje u kojemu se uspostavlja stilističnost nalazi u fizičkom prostoru jarka. Jarak, dakle, sudjeluje u oblikovanju sinegdohalnosti, odnosno zatvorenosti, kao prostorna međustanka stripovskih kadrova, koja se može poistovjetiti s ulogom stranične praznine kao gradivnog elementa pjesničke strukture, posebice u intermedijalnoj, odnosno „poeziji iskustva jezika"11 gdje upravo bijela prostornost postaje ponekad i jedini sadržaj unutar okvira pjesničkoga teksta (primjerice, u tekstu Brezovačka abeceda ${ }^{12}$ Slavka

\footnotetext{
${ }^{9}$ Jarak je prostor između stripovskih kadrova. Ibidem, str. 66.

${ }^{10}$ M. Riffaterre, Kriteriji za stilsku analizu, „Quorum” br. 5/6, 1989, str. 535.

${ }^{11}$ Z. Mrkonjić, Suvremeno hrvatsko pjesništvo (razdioba), Zagreb 1971.

${ }^{12}$ S. Jendričko, Crvena planeta (1985), u: Orguljaš na kompjutoru, Sisak 1999, str. 66-67.
} 
Jendrička), čime se pojačava aktivnost čitatelja u proizvođenju ,mentalnih konstrukcija" (McCloud) što će povezati, odnosno odsemantizirati vidljivu - verbalnu/crtežnu znakovnost teksta.

Slikovna narativnost te odnos slikovne i verbalne razine također su mjesta iz kojih proizlazi kodnost poetskoga teksta, posebice u dijelovima koji žele naglasiti princip plošnosti, odnosno simultanog postavljanja tekstnih elemenata na straničnoj plohi.

Uloga subjekta u interkodnim kombinacijama pjesnički tekst-strip presudna je, kako se vidi, u smislu posredovanja konstrukcijskih principa stripa i kreiranja unutartekstualnog lika prema stripovskom modelu koji, potom, postaje metajezična informacija u odnosu na poetski tekst.

Stripovni subjekt u tekstovima intermedijalnog pjesništva pojavljuje se kao autentičan slikovni ili verbalno predstavljeni lik koji je u tekstu objektiviran imenom, trećim licem jednine ili čak drugim licem jednine, kada je moguće da je to Ti zapravo (auto)objektivirano Ja koje si odmakom priskrbljuje veću djelatnu kompetenciju.

S obzirom na subjektivitetnu razinu, moguće je razlikovati najmanje četiri modela prisutnosti stripovnoga koda u pjesničkome tekstu:

- stripovni subjekt kao autentičan stripovni crtežni lik preuzet iz stripa i prenesen u pjesnički tekst (Ljubomir Stefanović),

- preuzimanje stripovnoga lika na simboličkoj razini teksta, odnosno verbalno oblikovanje poznatoga stripovnog lika preuzetog iz postojećega strip-predloška i smještenog u verbalno odsimuliranu kadriranost stripa (Goran Rem),

- potpuno kodno preoznačavanje poznatoga stripovnog lika, odnosno njegova prilagodba verbalnoj kodnosti pjesničkoga teksta (Tomica Bajsić, Alen Galović),

- realizacija odsutnoga stripovnoga subjekta slikovnim metajezikom (Bruno Andrić).

Primjer za prvu stripovno-subjektnu situaciju je tekst Ljubomira Stefanovića 007. terroristen, ha ${ }^{13}$, koji preuzima autentičan stripovni kadar i pragmatičkim kontekstom - pjesničkom zbirkom, transformira ga u poetski tekst u kojemu dolazi do su-djelovanja Nad Ja subjekta i različitih subjekata u tekstu:

\footnotetext{
${ }^{13}$ Lj. Stefanović, Umnožena pjesan, Čakovec 1979, str. 61.
} 
007. terroristen, ha

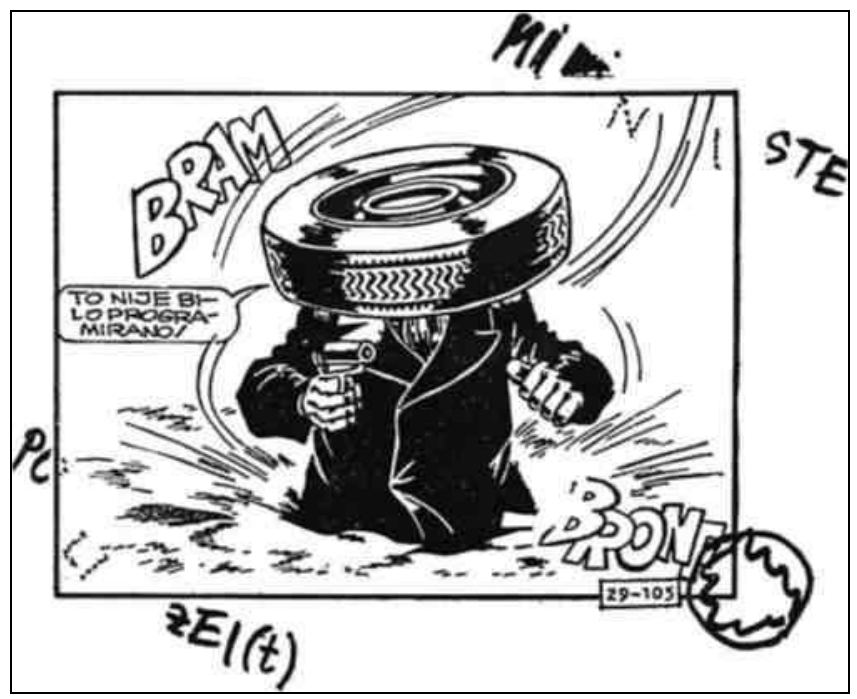

Djelovanje Nad Ja subjekta je metajezično - pomoću kombinacije slikovnoga i verbalnog jezika stripa implicitno komentira poetiku pjesničkoga teksta; čini to tako što autentični jezik stripa dekontekstualizacijom resemantizira u metajezik. Dakle, Nad Ja, pomoću metamedijske organizacije iskaza, uspostavlja metajezik pjesničkoga teksta. Pokazatelji prisutnosti izvantekstnog subjekta realizirani su troslojno - kao stripovnome kadru fizički nepripadajuće, prethodeće verbalne intervencije izvan i ispod (što je naznačeno rasteriziranim grafemima) stripovnoga pravokutnika (MI, VI, NI, STE, PO, LI, ZEI(t)), kao ikonička aplikacija na donjem desnom rubu kadra te kao supstituiranje sukcesije slikovnoga slijeda osamljenim stripovnim kadrom.

Spomenutom organizacijom različitih tipova znakovnosti ostvaruje se iluzija prostorne pod- i nad-postavljenosti, odnosno dubine, a ne linearnosti što je tipično za strip. Voluminacijom prostora tekst se bliži i trodimenzionalnim umjetnostima - skulpturi i arhitekturi, no ovdje je primarna sugestija takvoga znakovnog uslojavanja usmjerena realizaciji vremena. Dekonstruiranjem tipične formalne organizacije stripa svođenjem iskaza na jedan jedini kadar, ukida se kadrovna slijednost koja oponaša vremenski tijek; 
sve je zbivanje skoncentrirano unutar jednoga kadra i u njegovom neposrednom okružju, tako da se može govoriti o zamjeni linearne progresije (koja se konvencionalno ostvaruje jarcima kao kadrovnim međuprostorima imaginacijskog popunjavanja vremenskim i prostornim podatcima) simultanošću prostora i vremena. Upravo je simultanost rasprostorene organizacije tekstualne strukture ono što semiotička poezija promiče u cilju dekonstrukcije „okoštale” forme pjesmovne vertikale.

Druga važna strukturna napomena Nad Ja subjekta nalazi se u semantički višeslojnim i višeznačnim izvan- i pod-tekstnim leksemima koji odašilju barem dvostruku semantičnost - aludiraju na izvankadrovnu događajnost te na subjektne instance koje su njezin dio - POLIZEI, MI, VI. Dakle, sugestija prvoosobne subjektnosti zamjenicom MI svakako je djelo Nad Ja instance koja odmah osporava njezinu možebitnu strukturnu superiornost pretpostavljenom zamjenicom VI čija se slovna nejasnoća razotkriva pripadajućim glagolskim oblikom, točnije tek negacijskim (NISTE) ili afirmacijskim nenaglašenim oblikom pomoćnoga glagola biti u 2. licu množine (STE). Treba naglasiti kako je morfem NI rasteriziran u značenju nevidljivosti, prekrivenosti; semantički je inferiorniji od vidljivih pa to upućuje na svjesnu manipulaciju subjektivitetnom strukturom, odnosno kompetencijom subjektnih likova, od strane superiorne izvantekstualne instance. Time što moguću prvoosobnost odmah osporava zamjeničkim VI kojemu se predaje superiorna pozicija, Nad Ja uvlači u tekst čitateljsku instancu kao ravnopravni subjekt pa se može reći kako u izvantekstnom izvankadarskom prostoru, Nad Ja uspostavlja kontakt s instancom čitatelja čije sudjelovanje imperativno zahtijeva.

Zašto inolingvalni leksem PO LI ZEI(t)? Zbog toga što omogućuje intraleksemsku višesemantičnost, i na razini morfema, i na razini čitave riječi, te što sadrži morfem POLI koji je univerzalno semantičan, bez obzira na jezično područje. Leksem POLIZEI(t) također je prostorom rascjepkan na tri dijela, s tim što funkcija rastera u izvedbi morfema LI nije asocirati prekrivenost nego polistrukturnost, pogotovo što je takav rasterizirani morfem dio prefiksalnoga POLI čije značenje zapravo reflektira i čije se značenje reflektira kao svojevrsni ključ na čitav tekst, na sve tekstualne strukture (poliformnost, polisubjektnost, politematičnost, polistilističnost), pa i na sam leksem čiji je dio, a koji je udvojiv na riječi polizei i polizeit, što se sugerira grafemom $\mathbf{t}$ u zagradi na kraju riječi. Iako je izvedbeno dvo- 
struko marginaliziran - zagradom i maloslovnom izvedbom, upravo grafem $\mathbf{t}$ proizvodi dvoleksemsku semantičnost - istodobno označava subjektnu instancu čija se konvencionalna semantika veže uz pridržavanje pravila, održavanje reda (u pjesničkom tekstu) te perspektivu vremena, točnije polivremenitosti, koja oponira vremenskoj i, uopće, strukturnoj uređenosti, što ju implicira semantika leksema ,polizei”. Naime, kako nema slikovnoga slijeda, odnosno jaraka koji će odsimulirati vremenski tijek, vrijeme se rasplinjuje oko stripovnoga kadra i dobiva određene smjerove u korelaciji sa sadržajnom razinom na kojoj dominira subjektivitetni lik kao orijentacijska točka. Dakle, Nad Ja subjekt dekontekstualizacijom stripovnoga kadra i ubacivanjem verbalnih signala koji ga resemantiziraju, uvodi i unutarsubjektni lik čija je verbalna aktivnost također onda resemantizirana, točnije ometajezičena, pa replika koju izgovara: „To nije bilo programirano!", nadrasta konkretnu sadržajnu razinu i postaje metajezik čitave verbalno-slikovno-prostorne pjesmovne konstrukcije. Dolazi do zamjene manifestnih subjektnih funkcija - Nad Ja poprima značajke stripovnoga, metajezično aktivnoga subjekta, a izvorni stripovni subjekt resemantizacijom koju provodi Nad Ja, preuzima funkciju pjesničkoga subjekta, odnosno postaje identitetno nerazaznatljiv, ambivalentni lik. Izravni pokazatelj odnosa Nad Ja i Ja je guma koja prekriva glavu unutartekstnog subjekta, a dolazi iz vanjskoga prostora (ikonička signalizacija - linije pokreta, kaligramske oznake zvuka, intenziteta pritiska na unutartekstualnu instancu) iz prostora djelovanja Nad Ja.

Sučeljavanje nove i stare poetike vidljivo je i na razini intermedijalnih kontakata između dva antitetična medijska junaka - Jamesa Bonda i Alana Forda (iz stripa Alan Ford preuzet je i stripovni kadar). Dok naslovno prozvani lik aktivira jedan konvencionalni tip filmskoga tajnog agenta čije su profesionalno-karakterne osobine superlativne (James Bond), onaj iz teksta (Alan Ford) replicira mu osobinama antijunaka. Dakle, na relaciji film - strip događa se isto što i na relaciji strip - književnost. Najprije dekontekstualiziranje lika, a potom njegova resemantizacija u novome medijskom kontekstu u kojemu ta gostujuća znakovnost funkcionira kao metajezik preispitivanja ustaljenih strukturnih konvencija toga novoga medija-domaćina.

Nad Ja subjekt na spomenute načine, dekonstruirajući strukturne stripkonvencije, konstruira, također u odnosu na poetsku konvenciju, dekon- 
struirajući prostor intermedijalne poezije. Tako se metajezično djelovanje izvantekstnog subjekta reflektira na sve tekstualne strukture stavljajući ih u funkciju svoga metagovora.

Tekst Gorana Rema Naknadni dobri scenarij ${ }^{14}$ primjer je preuzimanja stripovnoga lika na simboličkoj razini teksta, odnosno verbalnog oblikovanja poznatoga stripovnog lika preuzetog iz postojećega strip-predloška o Taličnom Tomu (ili Luckyju Lukeu) i smještenoga u grafemskostrukturnu i formalno odsimuliranu kadriranost stripa:

\section{NAKNADNI DOBRI SCENARIJ}

prvi kvadrat

Talični Tom

stoji leđnonehajno oslonjen o šank

i slamčano cuga Coca-Colu

drugi kvadrat

Daltoni

treć i kvadrat

Nezgodno potežu

č etvrti kvadrat

Talični Tom

stoji leđnonehajno oslonjen o šank i slamčano cuga Coca-Colu

dock

se s ruba futrole, s nježno zamagljenog nicklovanog obruba, otkida

lelujavo treperavi plavičasti trag dima

novi kvadrat

Isključujem stroboskop

${ }^{14}$ G. Rem, Dobre oči tvoje, Zagreb 1996, str. 54. 
U ovom je tekstu zamjetna korelacija tri subjektne instance - Nad Ja, koja prevodi slikovno-verbalnu semiotiku stripa na verbalno-formalnu znakovnost poetskoga teksta, Ja koja je unutrašnji koordinator zbivanja te Talični Tom i Daltoni koji su objektivirani subjekti, dakle likovi smanjene kompetencije, svedeni na citat svoje funkcije što ju imaju u stripovnom događanju.

Ja subjekt, koji se pojavljuje tek u posljednjemu stihu, identificira njemu prethodeće informacije kao refleksiju vlastite recepcije, a, s obzirom na to, i sebesmještanjem u kontekst stripovnoga kadra, svoj lik kao stripovni, ali i metastripovni - aktivacijom gibanja stroboskopskom percepcijom koja implicira vremenitost trećega - filmskoga medija. Dakle, pozicioniranost i djelovanje Ja, koje je istodobno intramedijski stripovni subjekt, ali i eksterni metasubjekt - Nad Ja, u odnosu na percepcijom objektivirane subjekte - stripovne likove, otkriva metatekstnu, odnosno metamedijsku-metastripovnu strukturu teksta.

Upravo je subjektivitetna struktura Removog teksta pokazatelj i (pre)nositelj stilskih postupaka disimilacijskoga stripa koji sav upotrijebljeni kulturalno-civilizacijski materijal dekonstruira humornim interpretacijama, dvosmislenostima, disimilacijskim rezovima. Rem iz disimilacijskog stripa preuzima karikaturalnu reinterpretaciju žanra/lika/koda te, na formalnoj razini, funkciju stripovnih jaraka realiziranih međustrofnim prazninama u koje smješta didaskalijske intervencije subjekta teksta - najavljivača svakoga novog „kadra” (p rvi k vadrat, drug i k vadrat... itd.). Točnije rečeno, Rem koristi stripovnu interakciju vidljivog i nevidljivog (što potencijalno evociranog, što mentalno iskonstruiranog) kako bi uspostavio semantiku svojega teksta i kako bi u taj proces neizostavno uveo čitatelja - ali samo onoga koji ima potrebno čitateljsko-drugomedijsko iskustvo.

Objektivirani lik Taličnog Toma, oksimoroničan u svojoj karakterizaciji (fizički hiperkrhak, a snagom, neustrašivošću i moralom superioran), ovdje je predstavljen samo svojim činom-događajem, a ne deskripcijom fizičkog izgleda niti bilo kakvom pripovjednom intervencijom koja će pojasniti njegov izvorni kontekst. Njegova identifikacija prepuštena je čitatelju, a osim kontekstualizacije, čitatelj treba domisliti i zbivanja u međustrofnim prazninama (svojevrsnim poetskim jarcima) te ih semantički kontekstualizirati i spram određenog žanra filmskoga medija. Fabu- 
larna sukcesivnost postoji, no uz visoki stupanj redukcije događajnih podataka. Zapravo vrlo slično kao u tradicionalnom pjesničkom tekstu koji posreduje kakvu lirsku radnju pa se može pretpostaviti kako je jedna od mogućih namjera ovoga teksta bila preispitati mogućnosti prijenosa pjesmovne poruke strukturnim konvencijama drugoga medija. Drugim riječima, čitatelj mora percipirati tekst kao strip te to iskustvo iskoristiti kako bi ga razumio kao pjesmu. Do posljednje strofe pritajeni Ja subjekt u ovome tekstu karikiranjem tipičnih značajki vestern-junaka (savršena etičnost, hrabrost i fizička snaga herojskoga pojedinca) dekonstruira čitav semiotički, tj. semantički sustav vestern-žanra (,odnos pojedinac protiv sila zla” hiperbolično je karikiran, što se reflektira na sve ostale sastavnice žanra), čime se u korelaciju pjesma-strip uvodi i medij filma, koji je zapravo prototekst palimpsestiranoga stripa o Luckyju Lukeu, a što medijski-stripovni subjekt pjesničkoga teksta čini dvostruko, odnosno trostruko metaangažiranom instancom (spram filma, stripa i poetskoga koda).

Karikaturalno opisivanje lika poveznica je s medijem pjesničkoga teksta na dva načina - ,,apstraktnost karikature zahtijeva višu razinu opažanja što ju približava riječima koje su apstrakcija" ${ }^{15}$; i drugo, karikaturalni prikaz subjekta, subjektnih relacija i situacija, fokusira i hiperbolizira mjesta odstupanja od žanrovskih/strukturnih konvencija, što je kao komentar primjenjivo na oba vidljiva medija - pjesmovni i stripovni, s tim da, opet subjektovom percepcijskom aparaturom (stroboskopom) sugeriran zaleđni filmski medij, naglasak stavlja na pokret, odnosno na vrijeme kao strukturno važnu dimenziju koju i pjesnički tekst, i strip osjećaju kao svoju strukturnu uskratu, kao predodžbu koju žele proizvesti pa traže određeno opipljivo perceptivno pokriće. ${ }^{16}$ Zato je Ja subjekt čak trostruko kodiran, kako se već ranije napomenulo, te takva njegova kodnost postaje i njegov metajezični tekstni angažman.

Preoznačavanje semantike žanra, odnosno subjekta-nosioca žanra kakvo provodi strip Alan Ford u odnosu na žanr kriminalističkoga-špijunskoga filma (što se vidjelo u tekstu Ljubomira Stefanovića), primijenjeno je i u stripu Talični Tom, u kojemu je također subjekt nositelj humornoga preoznačavanja žanra vesterna koje se provodi djelovanjem instance Ja

${ }^{15}$ S. McCloud, Kako čitati strip..., str. 49.

${ }^{16}$ Opširnije o modelima izazivanja predodžbi u filmu i književnosti piše Hrvoje Turković u: H. Turković, Razumijevanje filma, Zagreb 1988, str. 181-191. 
subjekta. Upravo je Ja subjekt onaj koji te preoznake interpretacijom stripovnoga lika posreduje te je stoga njegova interpretacija metajezik koji razotkriva i njega samoga kao komentatora, i to kao onoga koji se fizički nalazi unutar stripa, kao stripovni lik-narator. Tako je preko subjektnih lica moguće razlikovati nekoliko tekstnih slojeva - strip unutar stripa unutar pjesničkoga teksta, a u odnosu na implicitno naznačen filmski prototekst. Filmična subjektna pod-svijest, kako se već napomenulo, upozorava na protok vremena koji u verbalnome mediju oponaša stripovski način realizacije vremenskoga tijeka tako što „mentalne” jarke zamjenjuje dvostruka znakovnost - verbalna sintagma šroko razmaknutih grafema i „optička realizacija prostora kao prostornosti" ${ }^{17}$, čija je izvedba materijalizacija djelovanja Nad Ja instance.

Potpuno kodno preoznačavanje poznatoga stripovnog lika, odnosno njegova prilagodba kodnosti pjesničkoga teksta, provedena je u poeziji Tomice Bajsića koja je tematski palimpsest stripova Huga Pratta. Tako je u pjesmi H.P. (in memoriam Hugo Pratt) ${ }^{18}$ kompletna aktantska struktura preuzeta iz Corta Maltesea pa će onda i subjektne funkcije biti prilagođene verbalnome mediju:

H.P.

$x$

Bahia. Zlatousta čeka na plavom prozoru.

Jutros je zapalila svijeću van vjetra

U rupi u pješčanom zidu među

Oštrim bridovima, algama, otplavinama.

Pustila je stručak cvjetova u vodu

(Trik iz Salvadora)

Da vidi hoće li ga more vratiti.

Ali nije.

(Mreža za spavanje na trijemu je prazna, to je njegova mreža.)

Umjesto njega na vrhu vala su došla djeca, dar pjene, male

Crne točke u dugačkom popodnevu. U njihovim dječjim očima

${ }^{17}$ Z.J. Šmit, Estetski procesi, Niš 1975, str. 184.
${ }^{18}$ T. Bajsić, Južni križ, Zagreb 1998, str. 18-19. 
Rebra slomljenih ribarskih čamaca

Postaju rebra nasukanih kitova. Atlantik sijeva

U stablima eukaliptusa.

$x x$

Kiša. Limeni oblaci lutaju zemljom. Trava uranja u ocean.

Voda se diže preko kotača automobila. Stajem na pola puta.

Red zemljanih koliba u jarku. Ispred kantine bilijarski stol sa

stolicom umjesto jedne noge. Magarac vezan uz stup i

zaboravljen. SEVEN-UP. Svjetlost se prima za vrhove drveća.

Zatvaram prozore. Mašina pušta paru. Kiša odnosi granje i šiblje.

Voda vri. Horizont nestaje. Lava nadire iz skrivenih bunara.

Radio se gasi. Brazil šuti.

Brazil je svijetložuta pukotina u mutnom nebu,

koridor za ptice.

Brazil su njegovi ljudi od crne tinte.

Uskoro, ova cesta će postati rijeka koja će se spojiti s morem,

Voda će se uliti u vodu i razlike će nestati.

$x x x$

Tvoj mornar je mrtav, Zlatousta.

Vidio sam ga noćas u dva sata ujutro. Stajao je sam

Na palubi broda upravljenog za Argentinu i pio iz boce.

Njegove oči su na crno-bijeloj fotografiji izgledale neprobojno.

Prkos ih je činio flourescentnima.

Zadignuo je ovratnik na kaputu, trudio se djelovati opasno

Ali vidjelo se da je blag i plemenit.

U ruci je držao koncem u križ opšiveni crveni

Kvadratić na kojem piše XANCÔ ili nešto slično.

„Gringova macumba”, rekao je i nestao.

(in memoriam Hugo Pratt)

Tekst je organiziran poput stripovskog događanja; podijeljen je u tri tematska segmenta u okviru kojih djeluju tri različita subjekta. Unutar tih segmenata informacije su grupirane u prizorno-događajne podskupine kadrove ili sekvence, odvojene bjelinama koje zatvaraju-razdvajaju razli- 
čite prostorno-vremenske odsječke, baš kao jarci u stripu. Subjektne instance koordiniraju pomicanjem informacija s perifernih dijelova stripovnoga događanja prema samome središtu, tako da spomenuti segmenti djeluju kao stupnjevi gradacije prostora i vremena kroz subjektivitetne likove. Tako u prvome dijelu govorna aktivnost Nad Ja svjedoči o vanjskoj, deskripcijskoj perspektivi promatračke instance koja se uobličuje u komentatorski tekst što projicira zamrznuto vrijeme predstavljenih informacija o liku i događaju kojim je taj lik određen i prostoru. $U$ drugome dijelu Nad Ja se zamjenjuje prvoosobnim subjektom koji je dio događanja, ali još uvijek kao promatračka instanca, dok u trećemu Ja postaje dio komunikacijske situacije, potpuno uronjen u radnju. Uz likove, kao prepoznatljive signale stripovnoga prototeksta, verbalni ekvivalenti stripovne slikovnosti su kratke, prezentske rečenice koje se referiraju na likove, događaje i prizore različite prostorne i vremenske smještenosti, čime se stavljaju u sinkronitet, u prostornu simultanost rascjepkanu bjelinama koje impliciraju vremenski tijek, što je tipično rješenje stripovne umjetnosti. ${ }^{19}$

Bajsić, kako se vidi, na posve drukčiji način koristi strukturne elemente određene stripovne poetike nego Goran Rem. Dok Rem, služeći se instancom subjekta i stripovnim jarcima, provjerava mogućnost izricanja fabulirane lirske radnje stripovnom strukturom narativnosti, Bajsić potpuno orječuje subjekt i radnju stripa, zapravo čitavu jednu stripovnu poetiku, istražujući mogućnosti i učinke lirizacije stripovne konstrukcije, pri čemu mu je formalna transpozicija, čini se, sekundarna.

I Alen Galović, poput Tomice Bajsića, u svojoj poetskoj zbirci Srebrni $\operatorname{letać}^{20}$ vrši reinskripciju naslovno apostrofiranog stripa/stripovskog lika, s tim što Galović stripovni lik kontekstualizira u moguću sadašnjost prefunkcionalizirajući njegove moći, odnosno onemoćujući ga u moralno, humanitetno atrofiranom zemaljskom okružju. Kao simptom potpunog rastakanja humaniteta govorno dominantan lik subjekta teksta navodi vir-

\footnotetext{
${ }^{19} \mathrm{Na}$ sličan način koreliraju verbalni i slikovni znakovi na srednjovjekovnim slikama; A.A. Hansen-Löve piše kako su citati na slikama pretvoreni iz perfekta u prezent čime se slika i tekst stavljaju na sinkronijsku, čak akronijsku razinu - ističe se i konstitutivno simultani karakter verbalne i slikovne umjetnosti pred sukcesivnošću i historicitetom narativnog verbalnog i likovnog prikazivanja. A.A Hansen-Löve, Intermedijalnost i intertekstualnost. Problemi korelacije verbalne i slikovne umjetnosti - na primjeru ruske moderne, u: Intertekstualnost \& intermedijalnost, str. 69.

${ }^{20}$ A. Galović, Srebrni letač, Zagreb 2001.
} 
tualnu stvarnost - negativnu inačicu svemirskih prostranstava koja su prebivalište strip-junaka - Srebrnog Letača. Stripovski lik ovdje se javlja kao sugovorno lice, s tim što se Ti osoba pojavljuje i kao autoobjektivirano Ja i kao ispovjedni prostor subjekta teksta, s obzirom da njegova stripovna funkcija junaka koji se iz služenja zlu transformira u borca za pravdu, implicira potrebnu etičku kompetenciju. Alen Galović, dakle, semantiku stripovnog subjekta ostvaruje primarno na tematsko-motivsko-idejnoj razini pjesničkoga teksta. Fragmentarno koristeći funkcije poznatoga strip-juna$\mathrm{ka}$, točnije fingirajući dijaloško-ispovjedni odnos subjekta teksta i Ti subjekta-Srebrnog Letača, Galović komentira dehumaniziranu zbilju 21. stoljeća, ne prokazujući pritom eksplicitno, ali podrazumijevajući i sâm stripovni lik kao manifestaciju te zbilje.

Realizacija odsutnoga stripovnog subjekta slikovnim metajezikom može se razmotriti kao subjektivitetna struktura pjesme Brune Andrića Balon $^{21}$ :

\section{BALON}

c s s s s s s s s s s s s s s s s s s s s s s s s s s s s s s s s s s s s s s s s s s s s s s s s s s s s s s s s s s s s s s s s s s s s s s s s s s s s s s s s s s s s s s s s s s s s s s s s s s s s s s s s s s s s s s s s s s s s s s s s s s s s s s s s s s s s s s s s s s s s s s s s s s s s s s s s s s s s s s s s s s s s s s s s s s s s s s s s s s s s s s s s s s s s s s s s s s s s s s s s s s s s s s s s s s s s s s s s s s s s

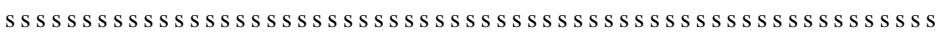
s s s s s s s s s s s s s s s s s s s s s s s s s s s s s s s s s s s s s s s s s s s s s s s s s s s s s s s s s s s s s s s s s s s s s s s s s s s s s s s s s s s s s s s s s s s s s s s s s s s s s s s s s s s s s s s s s s s s s s s s s s s s s s s s s s s s s s s s s s s s s s s s s s s s s s s s s s s s s s s s s s s s s s s s s s s s s s s s s s s s s s s s s s s s s s s s s s s s s s s s s s s s s s s s s s s s s s s s s s s s s s s s s s s s s s s s s s s s s s s s s s s s s s s s s s s s s s s s s s s s s s s s s s s s s s s s s s s s s s s s s s s s s s s s s s s s s s s s s s s s s s s s s s s s s s s s s s s s s s s s s s s s s s s s s s s s s s s s s s s s s s s s s s s s s s s s s s s s s s s s s s S s s s s s s s s s s s s s s s s s s s s s s s s s s s s s s s s s s s s s s s s s s s s s s s s s s s s s s s s s s s s s s s s s s s s s s s s s s s s s s s s s s s s s s

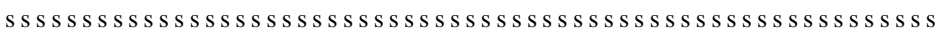
s s s s s s s s s s s s s s s s s s s s s s s s s s s s s s s s s s s s s s s s s s s s s s s s s s s s s s s s s s s s s s s s s s s s s s s s s s s s s s s s s s s s s s s s s s s s s s s s s s s s s s s s s s s s s s s s s s s s s s s s s s s s s s s s s s s s s s s s s s s s s s s s s s s s s s s s s s s s s s s s s s s s s s s s s s s s s s s s s s s s s s s s s s s s s s s s s s s s s s s s s s s s s s s s s s s s s s s s s s s s s s s s s s s s s s s s s s s s s s s s s s s s s s s s s s s s s s s s s s s s s s s s s s s s s s s s s s s s s s s s s s s s s s s s s s s s s s s s s s s s s s s s s s s s s s s s s s s s s s s s s s

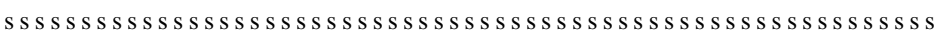

${ }^{21}$ B. Andrić, Zavod za zaštitu zdravlja, Osijek 1995, str. 43. 
Nad Ja uređuje tekst kao kaligramsku strukturu koja početnom grafemskom skupinom cs te u nastavku ponavljanjem grafema $\mathbf{s}$, oslikovljuje zvuk ispuhivanja balona. Riječ je o onomatopejskom postupku koji ujedinjuje vizualnu i akustičku razinu teksta ${ }^{22}$. Upravo je zvukovnost tekstna dimenzija čija se hipertrofiranost može tumačiti u kontekstu komentiranja konstruktivnog principa stripa koji počiva na kombinaciji riječi i crteža. Glasnoća i dužina ,ispuhivanja” zapravo je imperativni zahtjev za ukidanjem stripovnog balona koji je držač govornoga znaka, dakle pokazatelj prisutnosti govornoga, aktivnoga subjekta, pa se semantika ovoga teksta koji barata stripovnom znakovnošću može tumačiti kao „ispuhivanje” narcisoidnog subjekta kao superiorne intratekstualne strukture. Nad Ja, dakle, metamedijskim intervencijama (signaliziranjem odsutnosti stripovnoga subjekta) oblikuje metajezik poetskoga teksta kao komentar obrata subjektivitetne pozicije i funkcije u njemu.

\section{Zaključno}

Intermedijalni tekstovi suvremenog hrvatskoga pjesništva često kombiniraju vizualni i verbalni semiotički sustav ili potpuno podređuju verbalni znak vizualnom, odnosno prenose/interpretiraju vizualnu informaciju poetskim tekstom koji pritom rabi neverbalne semiotičke elemente (crtežnu ili fotografsku znakovnost i sl.) u dva semantička smjera - prema kulturalnom kontekstu, izvještajno, kritički, problemski, polemički repliciraju virtualnoj vizualizaciji svijeta 20. i 21. stoljeća, ${ }^{23}$ i prema unutra, prema vlastitome kodu, odoslovljuju značenje sintagme pjesnička slika, istražujući mogućnosti njene intersemiotičke ili inosemiotičke izvedbe. Kako je strip medij koji svojom semiotičkom hibridnošću i tematskim ulascima u najrazličitija kulturalna, društveno-povijesna, civilizacijska područja,

${ }^{22}$ Prema sličnim primjerima u: B. Vuletić, Jezični znak, govorni znak, pjesnički znak, Osijek 1988, str. 135-179.

${ }^{23} \mathrm{O}$ vizualnoj percepciji svijeta u 20. stoljeću kroz različite umjetničke i neumjetničke medije pogledati u: Vizualna kultura, ur. C. Jenks, Zagreb 2002 ili J. Užarević, Igra čarobnim zrcalom: vizualni kod dvadesetoga stoljeća, u: Ludizam: zagrebački pojmovnik kulture 20. stoljeća, ur. Ž. Benčić, A. Flaker, Zagreb 1996, str. 57-63. itd. 
svjedoči o medijskoj kulturi 20. i, posebice, 21. stoljeća, kao o kulturi posvemašnje citatnosti, odnosno intersemiotičnosti, a uz to je prostorna umjetnost poput poezije, mnogi ga autori suvremenog hrvatskoga pjesništva koriste kao prototekst provedbe dekonstrukcije poetskoga koda različitim provedbama postupaka intertekstualnosti i intermedijalnosti.

\section{Literatura}

\section{Predmetna}

Andrić B., Zavod za zaštitu zdravlja, Osijek 1995, str. 43.

Bajsić T., Južni križ, Zagreb 1998, str. 18-19.

Galović A., Srebrni letač, Zagreb 2001.

Jendričko S., Crvena planeta (1985), u: S. Jendričko, Orguljaš na kompjutoru, Sisak 1999, str. 66-67.

Rem G., Dobre oči tvoje, Zagreb 1996, str. 54.

Stefanović Lj., Umnožena pjesan, Čakovec 1979, str. 61.

\section{Teorijska}

Dragojević S., Frančeski H., Povijest stripa, u: Uvod u medije (zbornik), ur. Z. Peruško, Zagreb 2011, str. 173-201.

Hansen-Löve A., Intermedijalnost $i$ intertekstualnost. Problemi korelacije verbalne i slikovne umjetnost - na primjeru ruske moderne, u: Intertekstualnost \& intermedijalnost, ur. Z. Maković, M. Medarić, D. Oraić, P. Pavličić, Zagreb 1988, str. 31-74.

Ignjatović S., Poetizam stripa, Osijek 1979.

McCloud S., Kako čitati strip - nevidljivu umjetnost, Zagreb 2005.

Mrkonjić Z., Suvremeno hrvatsko pjesništvo (razdioba), Zagreb 1971.

Pavličić P., Intertekstualnost i intermedijalnost. Tipološki ogled, u: Intertekstualnost \& intermedijalnost, ur. Z. Maković, M. Medarić, D. Oraić, P. Pavličić, Zagreb 1988, str. 157-195.

Rem G., Koreografija teksta 1-2, Zagreb 2003.

Rem G., Pogo i tekst, Zagreb 2011.

Riffaterre M., Kriteriji za stilsku analizu, „Quorum” br. 5/6, 1989, str. 524-537.

Šmit Z., J., Estetski procesi, Niš 1975.

Turković H., Razumijevanje filma, Zagreb 1988. 
Užarević J., Igra čarobnim zrcalom: vizualni kod dvadesetoga stoljeća, u: Ludizam: zagrebački pojmovnik kulture 20. stoljeća, ur. Ž. Benčić, A. Flaker, Zagreb 1996, str. 57-63.

Užarević J., Kompozicija lirske pjesme, Zagreb 1991.

Vizualna kultura, ur. Ch. Jenks, Zagreb 2002.

Vuletić B., Jezični znak, govorni znak, pjesnički znak, Osijek 1988. 